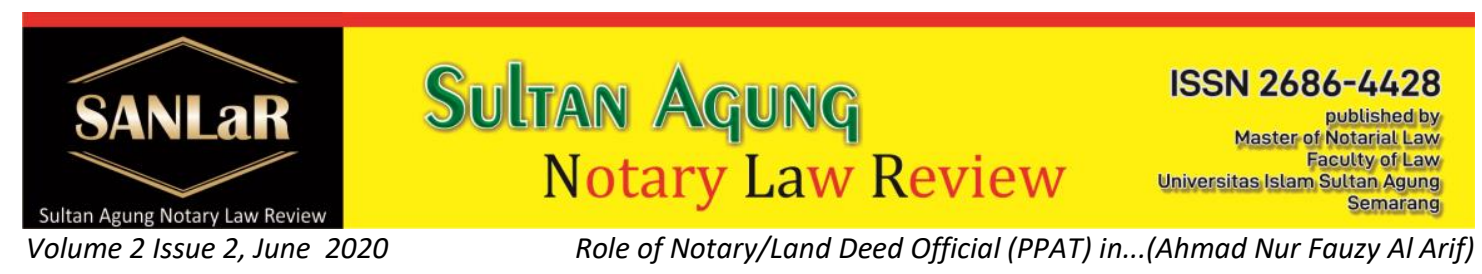

\title{
Role of Notary/Land Deed Official (PPAT) in Protection of Agricultural Land
}

\author{
Ahmad Nur Fauzy Al Arif ${ }^{*}$ and Widhi Handoko **) \\ *) Students of Master of Notary Law, Universitas Islam Sultan Agung (UNISSULA) \\ Semarang, E-Mail: ozynurfauzy@gmail.com \\ $\left.{ }^{* *}\right)$ Notary/PPAT in Semarang City
}

\begin{abstract}
Research Objectives for: 1) To determine the role of a Notary/Land Deed Official in the process of protecting Sustainable of Agriculture land. 2) To find out what are the obstacles and solutions in the implementation of Sustainable of Agriculture Land protection. The data used in this study are primary data, secondary data and tertiary data that can support assessment, which are then analyzed using empirical juridical methods. Based on the results of the data analysis it was concluded that: 1) in Act No. 41 of 2009 in Article 37 letter (e) explained about control by means of counseling this matter related to the role of a Notary/Land Deed Making Official automatically as a legal consultant and legal counsel to the people who use his services, this is related to three (3) work characteristics which in the first point explained that work must reflect the existence of a document that realizes a policy in this case related to the protection of Sustainable of Agriculture land. 2) in the implementation of Sustainable of Agriculture land protection is the lack of public knowledge about the rules regarding the protection of agricultural land, this is due to the lack of legal counseling related to this problem. The increasing number of population is also one of the factors inhibiting the implementation of protection of agricultural land, the increasing number of population certainly increases the need for residential houses, this is used as agricultural landowners as a business opportunity amid the difficulties of becoming farmers at this time, landowners are changing their land use. The farms are plots of land and housing and converted into industrial land. Solutions that the government can, especially the regional government embrace the Notary/PPAT in conducting counseling about the protection of agricultural land, because it will not be effective if the government conducts its own counseling, the construction of flats and industrial estates is a solution to the need for land for housing and industry. The increasing number of residents certainly increases the need for residential housing, this is used by agricultural landowners as a business opportunity in the midst of the difficulties of becoming farmers at this time, landowners are converting their agricultural land into land plots and housing and being converted into industrial land.
\end{abstract}

Keywords: Role; Notary; Protection; Agricultural Land.

\section{Introduction}

In a country, land becomes an important and strategic resource because land is related to the livelihoods of all people who live on it, land also has characteristics that are multidimensional, multisectoral and have high complexity. In addition, land also has a religious value that cannot be measured economically for a country. The issue of land 
is indeed a problem related to various interests, both economic, social, political, even for Indonesia.

Land is a means owned by a country to achieve prosperity for the life of its people, so the state must regulate in its preparation, in accordance with the constitutional mandate as stated in Article 33 paragraph (3) of the 1945 Constitution of the Republic of Indonesia, which reads: "The earth and water and the natural resources contained therein are controlled by the state and used as much as possible for the prosperity of the people"

then reaffirmed in Act No. 5 of 1960 on Basic Regulations on Agrarian Principles, hereinafter referred to as UUPA, in Article 2 paragraph (1), which reads: "Earth, water and space, including the natural resources contained therein are controlled by the state as an organization of power for all people"

As the holder of the highest rights of control of land, the state must regulate:

a. People's legal relationship with the land;

b. Legal actions of people on land; and

c. Planning the allocation of land use and use for public purposes.

Related to the control of land by the state, the state is required to make plans regarding the supply, designation, and use of the earth, water, space and wealth contained therein, in accordance with what is regulated in Article 14 of the BAL with the purpose of:

a. Necessity of State;

b. Purposes of worship and other sacred purposes, according to the Worship of the Almighty God;

c. Needs Centers of community life, social, cultural and other welfare;

d. The need to develop agricultural, livestock and fisheries production and in line with it;

e. Need to develop industry, transmigration and mining.

Regarding agriculture, it is certainly inseparable from land, land being a major factor in the world of agriculture. Indonesia as an agrarian country absorbs the most labor in the agricultural sector compared to other economic sectors, agriculture is one of the cornerstones of national development and plays an important role in the economy and the survival of the community, especially meeting food needs. Local food supply is the main focus of national food providers. Increasing population, economic activities, and food needs make efforts to achieve national food security in the future more severe.

The conversion of agricultural land to non-agricultural land functions is increasingly expanding in line with development policies that emphasize growth aspects through the ease of investment facilities, both to local and foreign investors in the provision of land. ${ }^{1}$ The increasingly narrow land is increasingly fragmented due to the need for housing and industrial land. Farmers prefer to work in the informal sector rather than

\footnotetext{
${ }^{1}$ Widjanarko, et al. (2006). Aspek Pertanahan Dalam Pengendalian Alih Fungsi Lahan Pertanian (sawah). Pusat Penelitian dan pengembangan BPN. Jakarta: BPN. p. 60
} 
survive in the agricultural sector. The declining attractiveness of the agricultural sector also makes farmers tend to be followed by land conversion. ${ }^{2}$

The implementation of land conversion is carried out with due regard to the role of the land for the public interest in human life, in relation to that, control of agricultural land is one of the national policies that is sufficiently appropriate to maintain the agricultural sector in the capacity of food providers in relation to preventing the decline in socioeconomic welfare levels in long term given the multifunctional nature of agricultural land. ${ }^{3}$ Uncontrolled transfer of agricultural land functions can threaten the capacity of food supply, and even in the long run can cause social losses. ${ }^{4}$

Aware of the increasingly worrisome condition of agricultural land due to conversion, the government and the House of Representatives passed Act No. 41 of 2009 on Protection of Sustainable of Agriculture Land. Protecting Sustainable of Agriculture land has the following objectives:

a. Protecting food agriculture land and land in a sustainable manner;

b. Guarantee the availability of Sustainable of Agriculture land for food;

c. Achieve food independence, resilience and sovereignty;

d. Protect the ownership of agricultural land owned by farmers;

e. Improving the prosperity and welfare of farmers and the community;

f. Increasing farmer protection and empowerment;

g. Increasing the provision of employment for decent lives;

h. Maintaining ecological balance; and

i. Realizing agricultural revitalization.

However, over time after the enactment of Act No. 41 of 2009 the implementation of the regulation has not been able to keep up with the ongoing land use change. The lack of coordination between the government, relevant agencies and the community is one factor that is still weak protection of agricultural land.

Communities who will carry out the sale and transfer of functions of their agricultural land, will come to the office of the Notary/Land Deed Official (PPAT). They will ask whether the land status can be continued or not. They will ask for the help of a Notary/Land Deed Official (PPAT) especially in relation to Recommendations from several related agencies or offices, thus the role of the Notary/Land Deed Official (PPAT) becomes very important in protecting LP2B.

Notary/Land Deed Official (PPAT) must provide the answer as it should, informing how the sequence and procedures must be carried out in the process of conversion of agricultural land to non-agricultural land. Informing about the existence of applicable laws and regulations related to the process of conversion of agricultural land to nonagricultural land, as well as the sale and purchase of agricultural land. Provide legal counseling and applicable legal rules. This is so that the community will get legal clarity

\footnotetext{
${ }^{2}$ Gunanto, ES. (2007). Konversi Lahan Pertanian Mengkhawatirkan. Jakarta: Raja Persada Grafika. p. 35

3 Directorate of Food and Agriculture. (2006). Strategi Pengendalian Alih Fungsi Lahan Pertanian, Kementrian Perencanaan Pembangunan Nasional/Bappenas. p.10

4 Iqbal, and Sumaryanto. (2007). Strategi Penegendalian Alih Fungsi Lahan. Bogor: Pusat Kebijakan Pertanian. p. 167
} 
and clear procedures for how they will transfer the function of their agricultural land. This is related to the work professionalism of a Notary/Land Deed Official (PPAT) which requires the existence of three work characteristics.

\section{Methods}

The method of approach used in this legal research is the empirical juridical approach method or socio legal research. A research specification is a descriptive study, describing or depicting the applicable laws and regulations relating to a particular situation or object factually and accurately. ${ }^{5}$ The method of collecting data uses library research methods and observation

\section{Results and Discussion}

\subsection{The Role of Land Deed Official in the Protection of Sustainable of Agriculture Land}

Officials who make land certificates that are also mentioned (PPAT) in UUPA (Act No. 5/1960) are not regulated, whereas Government Regulation No. 10 of 1961 on Land Registration regulates the authority of legal officials to make agreements in the process of transferring land rights.

This is not enough in its implementation due to the increasingly complex issue of transfer of land rights. Government Regulation Number 10 of 1961 on was later renewed with Government Regulation Number 24 of 1997 on Land Registration up to now specifically having been regulated in Government Regulation Number 37 of 1998 on Role Position of Land Deed Official as amended by Government Regulation Number 24 of 2016.

In Article 1 paragraph (1) of Government Regulation Number 37 of 1998 as amended by Government Regulation Number 24 of 2016 governing the definition of PPAT: "Public officials who are authorized to make authentic deeds concerning certain legal acts regarding land rights or rights Owned by Flats Unit. "

The definition of "public official" in Dutch is "Open Boar"/"Ambtenaar". "Open Boar" means relating to the government that handles affairs that are open to the public, so in the case of PPAT is included as a public official, because PPAT is appointed by the government and handles public affairs "Open Baur Ambienua", means the official in charge of making a public deed. ${ }^{6}$ R. Soegondo Motodisoerjo, explained that a person is appointed as a public official, if he is appointed and dismissed by the government and given the authority and obligation to serve the public in certain matters. Because, he participated in carrying out government authority. ${ }^{7}$

As explained above, the PPAT has the authority to make authentic deeds concerning certain legal actions regarding land rights, and also has authority in matters of land registration. In relation to the protection of Sustainable of Agriculture land PPAT has a very important role as an extension of the government to the community.

\footnotetext{
${ }^{5}$ Soekanto, Soerjono. (1986). Pengantar Penelitian Hukum. Jakarta: UI Pres. p.5

${ }^{6}$ John, Salindeho. (1987). Masalah Tanah dalam Pembangunan. Ujung Pandang: Sinar Grafika. p. 53

${ }^{7}$ lbid. p. 53
} 
In the community, legal actions in the form of buying and selling of land are common and of course the community will face the PPAT who is the official in charge of these legal actions. The community as a client will certainly inquire in advance the status of the land to be traded, whether it is grounds land, lots or agricultural land.

Regarding the sale and purchase of agricultural land in Act No. 41 of 2009 Article 50 paragraph (3) stipulates that the sale of agricultural land may be carried out, but on condition that it is not allowed to be converted into non-agricultural land, thus in each sale transaction buying agricultural land PPAT must know what the land will function after the sale and purchase transaction. If the land is to be converted into nonagricultural land whether it is used as housing or industry, the PPAT must check the status of the land in relation to the land zone and determine whether it is Sustainable of Agriculture Land or not.

PPAT is not only authorized to make deeds related to legal matters relating to land, but also automatically become consultants and legal counselors. In Act 41 of 2009 Article 37 letter e, control of Sustainable of Agriculture food lands by way of counseling. This is in accordance with the PPAT's function as a counselor, giving answers as they should, Informing how the sequence and procedures must be carried out in the process of transferring the function of agricultural land to non-agricultural land.

Informing about the existence of applicable laws and regulations related to the process of conversion of agricultural land to non-agricultural land. Provide legal counseling and applicable legal rules. This is so that people get legal clarity and clarity of procedures for how they will transfer the function of agricultural land. This is related to the work professionalism of a Notary/Land Deed Official (PPAT) which requires the existence of three work characteristics, namely: ${ }^{8}$

a. That the work reflects the existence of the intention to realize the virtues that are held in high esteem in the community, which therefore will not work that prioritizes or expects material rewards for the perpetrators, but the establishment of selfrespect;

b. That the work is carried out based on high quality technical skills, which is why it requires a very long time of exclusive and strenuous education and training;

c. That the technical and moral qualities that are highly required in the work of providing professional services in their implementation must submit to the control of fellow organized citizens, based on a code of ethics developed and mutually agreed upon in the organization whose violations will have consequences for violators before the Honorary Council.

\subsection{Obstacles and Solutions in Implementing Sustainable of Agriculture Land Protection}

in the implementation of a regulation or policy certainly will never be implemented perfectly, there will certainly be many factors that hinder and even hinder the

\footnotetext{
${ }^{8}$ Wignjosoebroto, Soetandyo. (2001). Profesi Profesionalisme dan Etika Profesi. Jakarta: Media Notariat. p. 32
} 
implementation of these regulations or policies, not least in the implementation of Act No. 41 of 2009 on the Protection of Sustainable of Agriculture Land.

There are many factors that support the implementation of protection of Sustainable of Agriculture Land, namely the vast area makes the government-carried out procurement less effective, counseling is carried out not reaching all levels of society, especially in the regions, this causes a lack of understanding and knowledge of the community regarding food agricultural land protection. Data in Central Java shows a decrease in the area of agricultural land in the form of irrigated rice fields from 2013, which was previously $4,817,170$ hectares, to $4,745,026$ hectares in $2017 .{ }^{9}$ This large decrease is an indication of the ineffectiveness of government counseling.

Then in addition to the lack of counseling, the high amount of community growth also causes the need for shelter to be higher, this is a factor driving the conversion of agricultural land into settlements. The landowners see that it is far more profitable so that the dry land becomes agricultural land and used as housing compared to agricultural land. In addition to being used as housing for the function of agricultural land, there are also many sectors of industry and public interests such as roads and others, in the industrial sector the price of agricultural land offered by investors at high prices makes the owners of agricultural land tempted when it is increasingly difficult to become farmers.

Lack of integration between government and related services such as land offices, onestop integrated licensing services, agriculture and food security services, spatial planning also becomes one of the factors of lack of protection of agricultural land, as well as a lack of supervision so that many people are converting agricultural land without permission and without report.

While the inhibitor in carrying out the role of the Notary/PPAT in protecting agricultural land is a moral factor, many notaries/PPAT know the rules that apply but do not provide counseling to their clients because they are tempted by the nominal offered.

The solution that can be done to overcome the lack of counseling done by the government is to coordinate with the Notary/PPAT as an arm of the government to the community to conduct counseling related to the protection of Sustainable of Agriculture land because this is the people who carry out the sale or transfer of agricultural land will go to the office Notary/PPAT as an authorized official in this case Notary/PPAT becomes an official who is in direct contact with the community and is more effective in conducting public education directly to the people who will transfer their agricultural land functions.

Housing needs are increasingly high, and the needs of industrial land is expected by the government to provide solutions for the provision of flats that require less land but can float many people with adequate facilities, and the procurement of industrial estates is considered appropriate to coordinate land requirements for industry, in

\footnotetext{
${ }^{9}$ http://epublikasi.pertanian.go.id/epublikasi/statistik\%20data\%20lahan/, accessed on August 21, 2020
} 
addition it will be neatly arranged, the government will be better able to control industrial growth.

\section{Closing}

In the protection of sustainable food agricultural land the role of a Notary/PPAT is very important, in this case carrying out his functions as a consultant and legal counselor to the community who become his clients who use his services in the process of buying and selling as well as the conversion process as an appropriate extension target because they are direct to the perpetrators of conversion, because the counseling conducted by the government is less effective because it cannot reach the regions so that the information is not distributed evenly which causes many people to have less understanding of their agricultural land related to status and others.

\section{References}

\section{Journals:}

[1] Directorate of Food and Agriculture. (2006). Strategi Pengendalian Alih Fungsi Lahan Pertanian, Kementrian Perencanaan Pembangunan Nasional/Bappenas.

[2] Iqbal, and Sumaryanto. (2007). Strategi Penegendalian Alih Fungsi Lahan. Bogor: Pusat Kebijakan Pertanian.

[3] Soekanto, Soerjono. (1986). Pengantar Penelitian Hukum. Jakarta: UI Pres.

[4] Widjanarko, et al. (2006). Aspek Pertanahan Dalam Pengendalian Alih Fungsi Lahan Pertanian (sawah). Pusat Penelitian dan pengembangan BPN. Jakarta: BPN.

[5] Wignjosoebroto, Soetandyo. (2001). Profesi Profesionalisme dan Etika Profesi. Jakarta: Media Notariat.

Books:

[1] Gunanto, ES. (2007). Konversi Lahan Pertanian Mengkhawatirkan. Jakarta: Raja Persada Grafika.

[2] John, Salindeho. (1987). Masalah Tanah dalam Pembangunan. Ujung Pandang: Sinar Grafika.

Internet:

http://epublikasi.pertanian.go.id/epublikasi/statistik\%20data\%20lahan/_accessed on August 21, 2020 